\title{
Peningkatan Kompetensi Guru Binaan dalam Menyusun RPP melalui Bimbingan Berkelanjutan di SMKN 4 Lhokseumawe
}

\author{
Muhammad Yusuf Ismail \\ Pengawas SMK, Cabang Dinas Wilayah Lhokseumawe, Dinas Pendidikan Provinsi Aceh \\ *Corresponding Author. Email: my721161@ gmail.com
}

\begin{abstract}
This study aims to analyze the improvement of the teacher's ability in preparing Learning Implementation Plans (RPP) through continuous guidance at SMKN 4 Lhokseumawe with the instruments that have been prepared, namely in the form of observation sheets/observations of RPP components in accordance with Permendikbud No. 22 of 2016. This research method used school action research which is carried out for 3 months with two cycles. The subjects were 24 teachers. The research instruments were observation sheets, questionnaire, and interview guidelines. The data were analyzed by qualitative descriptive analysis. The result showed that coaching could improve the teachers' ability in designing lesson plan at SMKN 4 Lhokseumawe. The improvement of teacher competence through extensive supervision in the first and second cycles could be seen an increase in results. The average score in cycle 1 was 68,75 categorized moderate and the average score in cycle 2 was 85 categorized good where the improvement was $23,64 \%$. The capacity building in this study has proven that efforts to improve teachers' ability in preparing lesson plan through extensive supervision at SMKN 4 Lhokseumawe have obtained satisfactory results.
\end{abstract}

\begin{abstract}
Abstrak: Penelitian ini bertujuan untuk menganalisis peningkatan kemampuan guru dalam menyusun Rencana Pelaksanaan Pembelajaran (RPP) melalui bimbingan berkelanjutan di SMKN 4 Lhokseumawe dengan instrumennya yang telah disusun, yaitu berupa lembaran observasi/pengamatan komponen RPP sesuai dengan Permendikbud No. 22 Tahun 2016. Metode penelitian ini menggunakan penelitian tindakan sekolah yang dilaksankan selama 3 bulan dengan dua siklus. Subjek penelitian merupakan guru-guru binaan yang berjumlah 24 orang. Instrumen penelitian meliputi pedoman observasi, angket dan wawancara serta teknik analisis data yang digunakan adalah analisis deskripsi kualitatif. Hasil penelitian menunjukkan bahwa tindakan pembinaan dapat meningkatkan kemampuan guru dalam menyusun perangkat pembelajaran di SMKN 4 Lhokseumawe. Peningkatan kompetensi guru tersebut melalui bimbingan berkelanjutan pada siklus pertama dan siklus ke dua dapat dilihat terjadinya peningkatan hasil. Siklus pertama rata-rata skor akhir 68,75 berkatagori cukup dan siklus kedua rata-rata 85 dengan katagori baik dimana peningkatan terjadi sebesar 23,64\%. Peningkatan kemsampuan dalam penelitian ini benar telah membuktikan bahwa upaya meningkatkan kompetensi guru binaan dalam menyusun RPP melalui bimbingan berkelanjutan di SMKN 4 Lhokseumawe memperoleh hasil yang memuaskan.
\end{abstract}

\section{Article History}

Received: 07-08-2021

Revised: 09-09-2021

Accepted: 20-09-2021

Published: 05-10-2021

\author{
Key Words: \\ Extensive \\ Supervision, \\ Teachers \\ Competence, Lesson \\ Plan.
}

\section{Sejarah Artikel}

Diterima: 07-08-2021

Direvisi: 09-09-2021

Disetujui: 20-09-2021

Diterbitkan: 05-10-2021

\section{Kata Kunci: \\ Bimbingan \\ Berkelanjutan, \\ Kompetensi Guru, RPP.}

How to Cite: Ismail, M. (2021). Peningkatan Kompetensi Guru Binaan dalam Menyusun RPP melalui Bimbingan Berkelanjutan di SMKN 4 Lhokseumawe. Jurnal Paedagogy, 8(4), 467-474. doi:https://doi.org/10.33394/jp.v8i4.4120

https://doi.org/10.33394/jp.v8i4.4120

This is an open-access article under the CC-BY-SA License.

\section{Pendahuluan}

Pembaharuan pada bidang pendidikan nasional telah menetapkan visi pembangunan pendidikan nasional. Menurut Undang-undang Nomor 20 Tahun 2003 tentang Sistem Pendidikan Nasional yang menyatakan bahwa, visi pendidikan nasional adalah (1) 
mengupayakan perluasan dan pemerataan kesempatan memperoleh pendidikan yang bermutu bagi seluruh rakyat Indonesia; (2) membantu dan memfasilitasi pengembangan potensi anak bangsa secara utuh sejak usia dini sampai akhir hayat dalam rangka mewujudkan masyarakat belajar; (3) meningkatkan kesiapan masukan dan kualitas proses pendidikan untuk memaksimalkan pembentukan kepribadian yang lebih bermoral; (4) meningkatkan keprofesionalan dan akuntabilitas lembaga pendidikan sebagai pusat pembudayaan ilmu pengetahuan, keterampilan, pengalaman, sikap, dan nilai berdasarkan standar nasional dan global; dan (5) memberdayakan peran serta masyarakat dalam penyelenggaraan pendidikan berdasarkan prinsip otonomi dalam konteks Negara Kesatuan RI.

Berkaitan dengan visi pendidikan maka ditetapkan serangkaian prinsip penyelenggaraan pendidikan untuk dijadikan landasan dalam pelaksanaan reformasi pendidikan dan di antara prinsip tersebut adalah pendidikan diselenggarakan sebagai proses pembudayaan dan pemberdayaan peserta didik yang berlangsung sepanjang hayat (Supatma, 2015). Dalam hal tersebut diperlukan guru yang dapat memberikan keteladanan, meningkatkan kemauan, dan mengembangkan potensi serta kreativitas peserta didik. Guru yang memiliki kriteria tersebut dapat dikatakan sebagai guru yang professional.

Untuk mempersiapkan diri menjadi guru yang professional terdapat banyak upaya yang dilakukan. Hal ini sejalan dengan pendapat Imron (2000) yang menyatakan bahwa, (1) guru sering mengeluh kurikulum yang berubah-ubah; (2) guru sering mengeluhkan kurikulum yang sarat dengan beban, materi yang tumpang tindih; (3) seringnya siswa mengeluh dengan cara mengajar guru yang kurang menarik; dan (4) masih belum dapat terjaminnya kualitas pendidikan sebagai mana mestinya dan masih banyak hal-hal lain berupa temuan hari-hari yang mengambarkan bahwa kinerja sebagian guru memang masih kurang profesional. Selain empat hal yang disebutkan seperti di atas, meningkatkan kompetensi guru merupakan upaya yang harus dilakukan. Tujuan diadakannya kompetensi guru memiliki manfaat yakni, sebagai acuan pelaksanaan uji kompetensi, penyelenggaraan pendidikan dan latihan, dan pembinaan, maupun dasar bagi yang berkepentingan terhadap kompetensi guru untuk melakukan evaluasi, pengembangan bahan ajar dan sebagainya bagi tenaga kependidikan (Kusmiati, 2018). Berdasarkan kenyataan yang ditemukan, maka kinerja guru perlu ditingkatkan agar usaha membimbing peserta didik untuk belajar secara terus menerus dapat berkembang.

Proses pengembangan kinerja guru terbentuk dan terjadi dalam kegiatan belajar mengajar di tempat mereka bekerja. Selain itu, kinerja guru dipengaruhi oleh hasil pembinaan, supervisi pembelajaran dan semangat kerja guru itu sendiri. Menurut Asmani (2012) supervisi adalah mengamati, mengawasi atau membimbing dan memberikan stimulus kegiatan-kegiatan yang dilakukan oleh sesorang dengan maksud mengadakan perbaikan. Tujuan diadakannya supervisi adalah agar suatu sekolah memenuhi standar nasional pendidikan yang telah ditetapkan oleh pemerintah.

BSNP (2007) menyatakan bahwa, "Standar proses meliputi perencanaan proses pembelajaran, pelaksanaan proses pembelajaran, penilaian hasil pembelajaran, dan pengawasan proses pembelajaran untuk terlaksananya proses pembelajaran yang efektif dan efisien". Dapat dikatakan bahwa standar proses bertujuan untuk menciptakan pembelajaran yang efektif dan efisien untuk peserta didik.

Pembelajaran dikatakan efektif ketika peserta didik dapat menyerap materi pelajaran dan efisien (Mulyono, 2012). Pembelajaran akan berlangsung efektif dan efisien apabila guru mampu merencanakan pelaksanaan pembelajaran itu sesuai dengan kegiatan pelaksanaannya yaitu pembelajaran aktif, efektif dan menyenangkan dimana anak terlibat secara langsung dan diposisikan sebagai subjek dalam proses pembelajaran. Di samping itu, keberlangsungan 
standar proses atau pelaksanaan pembelajaran terdiri dari tiga macam kegiatan yaitu kegiatan pendahuluan, kegiatan inti yang terdiri dari eksplorasi, elaborasi dan konfirmasi serta penutup. Serangkaian kegiatan pembelajaran yang dimaksud tertuang dalam Rencana Pelaksanaan Pembelajaran (RPP).

Menurut Permendikbud Nomor 22 Tahun 2016 tentang Proses Pendidikan Dasar dan Menengah menyatakan bahwa:

"Rencana Pelaksanaan Pembelajaran (RPP) adalah rencana kegiatan pembelajaran tatap muka untuk satu pertemuan atau lebih. RPP dikembangkan dari silabus untuk mengarahkan kegiatan pembelajaran peserta didik dalam upaya mencapai Kompetensi Dasar (KD). Setiap pendidik pada satuan pendidikan berkewajiban menyusun RPP secara lengkap dan sistematis agar pembelajaran berlangsung secara interaktif, inspiratif, menyenangkan, menantang, efisien, memotivasi peserta didik untuk berpartisipasi aktif, serta memberikan ruang yang cukup bagi prakarsa, kreativitas, dan kemandirian sesuai dengan bakat, minat, dan perkembangan fisik serta psikologis peserta didik. RPP disusun berdasarkan KD atau subtema yang dilaksanakan kali pertemuan atau lebih".

RPP memiliki beberapa komponen yang telah ditetapkan. Menurut versi yang telah ditetapkan Permendikbud No. 22 Tahun 2016 "Komponen RPP terdiri atas: (a) identitas sekolah; (b) identitas mata pelajaran atau tema/subtema; (c) kelas/semester; (d) materi pokok; (e) alokasi waktu; (f) tujuan pembelajaran; g) kompetensi dasar dan indikator pencapaian kompetensi; (h) materi pembelajaran; (i) metode pembelajaran; (j) media pembelajaran; (k) sumber belajar; (l) langkah-langkah pembelajara; dan $(\mathrm{m})$ penilaian hasil pembelajaran".

Untuk menyusun RPP ada beberapa prinsip yang harus dipenuhi. Berdasarkan Permendikbud No. 22 Tahun 2016 menyatakan dalam menyusun rencana pelaksanaan pembelajaran harus memperhatikan prinsip-prinsip sebagai berikut: (a) perbedaan individual peserta didik; (b) partisipasi aktif peserta didik; (c) berpusat pada peserta didik untuk mendorong semangat belajar; (d) pengembangan budaya membaca dan menulis; (e) pemberian umpan balik dan tindak lanjut; (f) penekanan pada keterkaitan dan keterpaduan, antara KD, materi, kegiatan pembelajaran, indikator, Penilaian dan sumber belajar; (g) mengakomodasi pembelajaran tematik-terpadu; (h) penerapan teknologi informasi dan komunikasi secara terintegrasi. RPP yang disusun haruslah sesuai dengan prinsip-prinsip yang telah ditetapkan seperti yang di atas.

Selain komponen dan prinsip, adapula unsur-unsur lain yang harus diperhatikan ketika seorang guru membuat RPP. Menurut Kunandar (2011:265), unsur-unsur yang perlu diperhatikan dalam penyusunan RPP adalah: 1) berpatokan pada kompetensi dan kemampuan utama yang harus dikuasai siswa, materi dan sub materi pembelajaran, pengalaman belajar yang dirancang dalam silabus; 2) menggunakan berbagai pendekatan pembelajaran yang cocok dengan materi yang memberikan kecakapan hidup (life skill) sesuai dengan permasalahan dalam lingkungan sehari-hari; 3) menggunakan metode dan media sesuai, yang mendekatkan siswa dengan pengalaman langsung; dan 4) penilaian dengan sistem pengujian menyeluruh serta berkelanjutan didasarkan pada sistem pengujian yang dikembangkan selaras dengan pengembangan silabus.

RPP dikembangkan melalui silabus yang disediakan. Penyusunan Silabus dan RPP disesuaikan pendekatan pembelajaran yang digunakan. Silabus adalah rencana pembelajaran pada suatu dan/atau kelompok mata pelajaran/tema tertentu yang mencakup standar kompetensi, kompetensi dasar, materi pokok/pembelajaran, kegiatan pembelajaran, indikator, penilaian, alokasi waktu, dan sumber/bahan/alat belajar (Supinah, 2008:6). 
Sejalan dengan implementasi kurikulum 2013 yang sangat berpengaruh bagi guru dalam menentukan tujuan pembelajaran pada RPP guru harus bisa memilih metode dan menentukan pendekatan, model yang akan dipilih dalam pembelajaran, kelengkapan ini dirumuskan dalam sebuah RPP. Pada masa ini kurikulum yang digunakan adalah kurikulum 2013 atau yang lebih dikenal dengan K-13. Dalam menyukseskan implementasi K-13 perlu dipahami dan didukung oleh semua pihak dimana guru merupakan ujung tombak pelaksana pembelajaran harus melakukan penyesuaian sesuai dengan tuntutan serta pemerintah sebagai pemegang dalam hal kebijakan, memfasilitasinya dengan perangkat hukum seperti undangundang dan berbagai peraturan pemerintah, yang dalam proses pengimplementasiannya perlu dibangun kembali dan dijadikan modal awal oleh para pelaksana kurikulum di sekolah khususnya dalam pembelajaran (Idris, 2014:7). Jadi guru tidak hanya perlu memahami komponen-komponen RPP akan tetapi juga harus memahami prinsip-prinsip dalam penyusunannya. Namun, kemampuan guru dalam menyusun RPP masih menjadi sorotan supervisi.

Berdasarkan hasil supervisi pengawas, menunjukkan bahwa kemampuan guru binaan dalam menyusun perencanaan pelaksanaan pembelajaran yang sesuai dengan Permendikbud No 22 Tahun 2016 tentang Standar Proses Pendidikan Dasar dan Menengah masih kurang. Realita tersebut yang mendorong peneliti untuk melakukan pelatihan, guna meningkatkan kemampuan guru binaan dalam membuat perencanaan pelaksanaan pembelajaran sesuai dengan standar proses. Tindakan yang dilakukan pengawas sebagai upaya meningkatkan kemampuan guru binaan adalah melakukan bimbingan berkelanjutan dengan menggunakan metode diskusi kelompok kecil, pemberian tugas mandiri.

Hikmahwati (2011) yang menyatakan, bahwa bimbingan merupakan salah satu bidang dan program dari pendidikan, dan program ini ditujukan untuk membantu mengoptimalkan perkembangan siswa ataupun layanan khusus yang berbeda dengan bidang pendidikan lainnya. Sedangkan Menurut KBBI (2018), "Berkelanjutan adalah berlangsung terus menerus, berkesinambungan". Menurut Panigoro (2018:150) "Bimbingan berkelanjutan adalah pemberian bantuan yang diberikan seorang ahli kepada seseorang atau individu secara berkelanjutan berlangsung secara terus menerus untuk dapat mengembangkan potensi dirinya secara optimal dan mendapat kemajuan dalam bekerja". Untuk lebih jelasnya dapat disimpulkan bahwa, bimbingan berkelanjutan merupakan pemberian bantuan kepada individu secara berkelanjutan dan sistematis yang dilakukan oleh seorang ahli yang telah mendapat latihan khusus untuk itu, dimaksudkan agar individu dapat memahami dirinya sendiri, lingkungannya, serta dapat mengarahkan dan menyesuaikan diri dengan lingkungan untuk dapat mengembangkan potensi diri dengan optimal untuk kesejahteraan dirinya dan masyarakat. Melalui metode diskusi diharapkan guru aktif dalam berinteraksi pada kelompoknya dan mampu menghasilkan produk satuan RPP sesuai dengan K-13. Sedangkan melalui tugas mandiri diharapkan setiap guru binaan mampu menyusun RPP secara individu.

Peningkatan kinerja guru SMKN 4 Kota Lhokseumawe merupakan hal yang sangat mendesak, maka sebagai pengawas pembina melakukan penelitian tindakan sekolah yang bertujuan untuk untuk menganalisis peningkatan kemampuan guru dalam menyusun RPP melalui instrumennya yang telah dirancang, yaitu berupa lembaran observasi/pengamatan komponen RPP sesuai dengan Permendikbud No. 22 Tahun 2016.

\section{Metode Penelitian}

Penelitian ini menggunakan Penelitian Tindakan Sekolah (School Action Research) yang dilakukan dengan tujuan untuk meningkatkan kompetensi guru binaan dalam RPP dengan 
lengkap sesuai dengan Kurikulum 2013. PTS merupakan salah satu jenis penelitian untuk menemukan, atau mencari kebenaran dari sebuah dugaan mengenal ada 6 teori kebenaran (theories of thruth), yaitu 1) kebenaran korespondensi, 2) kebenaran konsistensi, 3) kebenaran koherensi, 4) kebenaran pragmatis, 5) kebenaran performatif, dan 6) kebenaran konsensus (Wayan, 2010). Metode yang digunakan dalam penelitian ini adalah metode deskriptif, dengan menggunakan teknik persentase untuk melihat peningkatan yang terjadi dari satu siklus ke siklus berikutnya.

Penelitian ini dilakukan di sekolah binaan, yaitu SMK Negeri 4 Lhokseumawe. Subjek dalam Penelitian Tindakan Sekolah (PTS) ini adalah guru binaan di SMK Negeri 4 Kota Lhokseumawe yang berjumlah 24 orang guru. Penelitian ini dilaksanakan selama 3 bulan, yakni dari bulan Februari sampai dengan akhir April 2020.

Penelitian tindakan sekolah ini dilaksanakan melalui dua siklus, yaitu siklus pertama dan siklus ke dua guna untuk melihat sejauh mana terjadi peningkatan kompetensi guru dalam menyusun RPP. Sumber data yang digunakan dalam penelitian ini yaitu RPP yang dibuat oleh guru. Berikut alur penelitian yang digunakan pada penelitian ini.

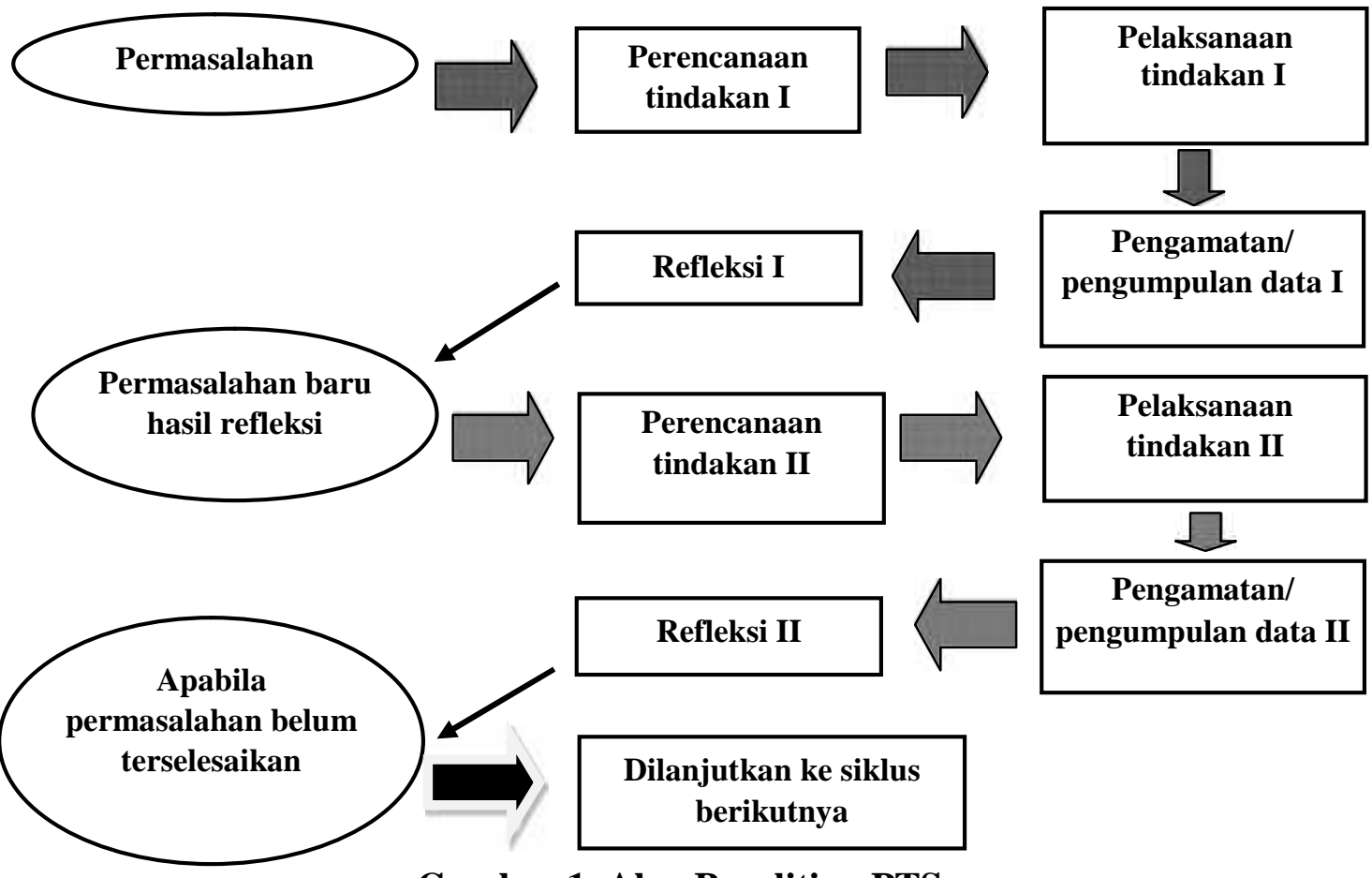

Gambar 1. Alur Penelitian PTS

Teknik pengumpulan data dalam penelitian ini adalah wawancara, Pengamatan/observasi, dan diskusi. Adapun alat pengumpulan data berupa panduan wawancara, lembar observasi dan untuk kegiatan diskusi dilakukan dengan sharing pendapat antara pengawas peneliti dengan guru. Sedangkan teknik analisis data yang digunakan adalah analisis deskripsi kualitatif

\section{Hasil Penelitian dan Pembahasan}

Untuk meningkatkan kompetensi guru binaan dalam menyusun RPP peneliti melakukan penelitian tindakan kelas yang dilaksanakan dalam dua siklus. Berikut hasi yang diperoleh dari masing-masing siklus: 


\section{Deskripsi Siklus I (Pertama)}

Siklus pertama terdiri dari empat tahap yakni: (1) perencanaan, (2) pelaksanaan, (3) observasi, dan (4) refleksi. Kegiatan diawali dengan observasi yang dilakukan peneliti terhadap dua puluh empat (24) orang guru binaan (responden) di SMKN 4 Lhokseumawe. Semuanya menyusun RPP, tetapi masih belum lengkap sebagaimana yang dikehendaki Permendikbud Nomor 22 Tahun 2016. Selanjutnya pengawas peneliti membimbing guru dengan model diskusi kelompok kecil, tutor sebaya dan meminta untuk melengkapi kekurangan RPP-nya.

\section{Deskripsi Siklus II (Kedua)}

Siklus kedua juga terdiri dari empat tahap yakni: (1) perencanaan; (2) pelaksanaan; (3) observasi; dan (4) refleksi. Peneliti melakukan observasi terhadap 24 orang guru binaan. Semuanya telah menyusun RPP, tetapi masih ada dalam jumlah yang relatif kecil guru binaan yang kurang tepat dalam menentukan tujuan pembelajaran, penilaian, remedial dan pengayaan. Selanjutnya guru-guru tersebut dibimbing dan diminta untuk memperbaikinya.

Penelitian ini bertujuan untuk melihat peningkatan kemampuan guru dalam menyusun Rencana Pelaksanaan Pembelajaran (RPP) melalui instrumen yang telah dirancang yaitu berupa lembaran observasi/pengamatan komponen RPP sesuai dengan Permendikbud No.22 Tahun 2016. Penelitian Tindakan Sekolah ini dilaksanakan di SMKN 4 Kota Lhokseumawe Provinsi Aceh dengan jumlah responden sebanyak 24 orang, dan dilaksanakan dalam dua siklus. Kesemua guru binaan tersebut menunjukkan sikap yang baik dan menjadi termotivasi dalam menyusun RPP dengan benar dan lengkap. Hal ini peneliti ketahui dari hasil pengamatan pada saat melakukan wawancara dan bimbingan penyusunan RPP.

Hasil penelitian menunjukkan bahwa terdapat peningkatan kompetensi guru dalam menyusun RPP dari siklus ke siklus. Hal tersebut diperoleh dari hasil rubrik penilaian guru dalam menyusun RPP. Dari hasil yang diperoleh menunjukkan bahwa terjadi peningkatan pada setiap komponen RPP yang disusun guru. Adapun Peningkatan yang teradi pada setiap komponennya, yaitu 3,3\% untuk komponen identitas; 13\% untuk komponen kompetensi inti; 9,4\% untuk komponen kompetensi dasar; $24 \%$ untuk komponen indikator pencapaian Kompetensi; $37 \%$ untuk komponen tujuan pembelajaran; 25\% untuk komponen materi pembelajaran dan komponen pendekatan/model dan metode; $32 \%$ untuk komponen langkahlangkah kegiatan pembelajaran; 57\% untuk komponen penilaian hasil belajar dan pengayaan; serta $46 \%$ untuk komponen media/alat, bahan dan sumber belajar.

Secara keseluruhan diperoleh bahwa pada siklus pertama diperoleh rata-rata skor akhir sebesar 68,75 berkategori cukup dan pada siklus kedua diperoleh rata-rata skor 85 dengan katagori baik dengan peningkatan terjadi sebesar 23,64\%. Hasil peningkatan kemampuan dalam penelitian ini benar-benar telah membuktikan bahwa upaya meningkatkan kompetensi guru binaan dalam menyusun RPP melalui bimbingan berkelanjutan di SMKN 4 Lhokseumawe memperoleh hasil yang memuaskan. Hal ini sejalan dengan penelitian Sutardi (2017), Sukarni (2017), Yatmini 92016), dan Purnamaraya (2019), yang juga menunjukkan bahwa penerapan bimbingan berkelanjutan dapat meningkatkan kompetensi guru dalam menyusun RPP.

\section{Kesimpulan}

Berdasarkan hasil penelitian tindakan sekolah yang dilakukan, maka dapat disimpulkan bahwa upaya meningkatkan kompetensi guru dalam menyusun RPP melalui bimbingan berkelanjutan sangat menggembirakan hasilnya. Hal itu bisa dibuktikan dari hasil observasi/pengamatan penyusunan RPP yang memperlihatkan bahwa terjadi peningkatan 
kompetensi guru binaan dari siklus awal ke siklus berikutnya. Pada siklus pertama diperoleh rata-rata skor akhir sebesar 68,75 berkategori cukup dan pada siklus kedua diperoleh rata-rata skor 85dengan katagori baik peningkatan terjadi 23,64\%.

\section{Saran}

Penelitian tindakan sekolah ini membuktikan bahwa dengan adanya bimbingan berkelanjutan, adanya peningkatan kompetensi dan motivasi guru dalam menyusun RPP. Oleh karena itu, pengawas peneliti menyampaikan saran sebagai berikut, yaitu motivasi yang sudah tertanam khususnya dalam hal penyusunan RPP hendaknya terus dipertahankan dan ditingkatkan. Guru juga senantiasa perlu terus belajar untuk menyempurnakan RPP dan menyelenggarakan RPP sesuai dengan yang telah disusun.

$\mathrm{rti}$

\section{Daftar Pustaka}

Asmani, J.M. (2012). Tips Efektif Supervisi Pendidikan Sekolah. Yogyakarta: Diva Press.

BSNP (Badan Standar Nasional Pendidikan). (2007). Peraturan Menteri Pendidikan Nasional Republik Indonesia Nomor 41 Tahun 2007 Tentang Standar Proses untuk Satuan Pendidikan Dasar dan Menengah. Jakarta.

Hikmahwati, F. (2011). Bimbingan Konseling. Jakarta: Rajawali Press.

Idris, Z. (2014). Resume Buku Guru dalam Implementasi Kurikulum 2013. Bandung: Universitas Islam Nusantara Bandung.

Imron, A. (2000). Pembinaan Guru Di Indonesia. Malang: Pustaka Jaya.

KBBI, (2016). Kamus Besar Bahasa Indonesia (KBBI). https://www.kbbi.web.id/lanjut.

Kunandar. (2011). Guru Profesional (Implementasi Kurikulum Tingkat Satuan Pendidikan dan Sukses dalam Sertifikasi Guru). Jakarta: Raja Grafindo Persada.

Kusmiati. 2018. Upaya Meningkatkan Kompetensi Guru dalam Menyusun Rencana Pelaksanaan Pembelajaran Melalui Bimbingan Berkelanjutan di SMP Negeri 23

PPU Tahun 2018. Article. http://download.garuda.ristekdikti.go.id/

Mulyono. (2012). Strategi Pembelajaran. Malang: UIN-Maliki Press.

Panigoro, I. (2018). Pelaksanaan Bimbingan Berkelanjutan dalam Upaya Meningkatkan Kompetensi Guru Menyusun Rencana Pelaksanaan Pembelajaran di SDN 01 Popayato. AKSARA, 4(2), 145-158.

Peraturan Menteri Pendidikan dan Kebudayaan Nomor 22 Tahun 2016 tentang Standar Proses Pendidikan Dasar dan Menengah. Jakarta: Depdiknas.

Purnamaraya, S. (2019). Upaya Meningkatkan Kompetensi Guru Kelas dalam Proses Pembelajaran Berdasarkan Kurikulum 2013 Melalui Supervisi Akademik di SD $\begin{array}{llll}\text { Negeri } & 45 & \text { Mataram. Jurnal Paedagogy, } & 6(2),\end{array}$ doi:https://doi.org/10.33394/jp.v6i2.2531

Sukarni, Ani. (2017). Upaya Meningkatkan Kompetensi Guru dalam Menyusun Rencana Pelaksanaan Pembelajaran melalui Bimbingan Berkelanjutan di SD Negeri AlunAlun Kabupaten Subang Tahun 2014. BIORMATIKA: Jurnal Ilmiah FKIP Universitas Subang, 3(2).

Supatma, A. (2005). Upaya Peningkatan Aktivitas Siswa Pada Pembelajaran Matematika dengan Metode Group Investigation di Kelas VII pada MTs Muhammadiyah 1 Ponorogo 2014/2015. Skripsi. Universitas Muhammadiyah Ponorogo: Ponorogo.

Supinah. (2008). Penyusunan Silabus dan Rencana Pelaksanaan Pembelajaran (RPP) Matematika SD dalam Rangka Pengembangan KTSP. Yogyakarta: Pusat 
Pengembangan dan Pemberdayaan Pendidik dan Tenaga Kependidikan Matematika.

Sutardi. (2017). Peningkatan Kompetensi Menyusun RPP melalui Bimbingan Berkelanjutan Guru SD. Manajer Pendidikan, 11(4), 355-358.

Undang-undang Republik Indonesia Nomor 20 Tahun 2003 tentang Sistem Pendidikan Nasional. Jakarta: Depdiknas.

Wayan, AS., I. (2010). Akuntabilitas Kinerja Kepala Sekolah dan Penelitian Tindakan Sekolah Untuk Kepala Sekolah dalam Rangka Peningkatan Mutu Pembelajaran Serta Bahan Belajar Mandiri Dimensi Kompetensi Kepala Sekolah. Jakarta: AzZahra Books 8.

Yatmini, Y. (2016). Meningkatkan Kompetensi Guru dalam Penyusunan RPP yang Baik dan Benar Melalui Pendampingan Berbasis KKG di SDN Model Mataram. Jurnal Kependidikan: Jurnal Hasil Penelitian dan Kajian Kepustakaan di Bidang Pendidikan, Pengajaran dan Pembelajaran, 2(2). doi:https://doi.org/10.33394/jk.v2i2.462 